\title{
Maintenance of Popular Multivoltine Races for Seed Cocoon Generation and their Performance at Basic Seed Farms
}

\author{
K.M. Vijaya Kumari ${ }^{1 *}$, P. Sudhakara Rao ${ }^{1}$, R. Saravana Kumar ${ }^{1}$, \\ S. Vidyunmala ${ }^{1}$ and R.K. Mishra ${ }^{2}$ \\ ${ }^{1}$ Silkworm Seed Technology Laboratory, Central Silk Board, Kodathi, \\ Bangalore-500 035, India \\ ${ }^{2}$ National Silkworm Seed Organization, Central Silk Board, Banglore-560068, India \\ *Corresponding author
}

\section{A B S T R A C T}

Silkworm seed technology laboratory, Kodathi is producing P2 Dfls through Race maintenance programme in limited manner to supply selected Basic seed farms to rear and generate P1 seed cocoons for hybrid preparation to West Bengal in the event of seed crop

\section{Keywords}

Silkworm, Multivoltine, Maintenance, Nistari, M6DPC

Article Info

Accepted:

18 April 2019

Available Online:

10 May 2019 failures. In the present investigation, Nistari ecotypes Chalsa, Balapur and Debra, M6DPC were evaluated almost for 5 years. The mean performance of these breeds was shown significant differences for the majority of the traits with excellent pupation rate. The effective rate of rearing/ 10,000 larvae (ERR) by is 8927 in Chalsa, 9118 in Balapur, in Debra 8898 and 8843 in M6DPC. The ERR by weight is $8.96 \mathrm{Kg}$ in Chalsa, $8.66 \mathrm{Kg}$ in Balapur, $8.61 \mathrm{Kg}$ in Debra and 7.92 in M6DPC. The cocoon weight in Chalsa $0.800 \mathrm{~g}$, and $1.00 \mathrm{~g}$ in Balapur, $1.020 \mathrm{~g}$ in Debra, 1.060 and in M6DPC. The cocoon shell weight in Chalsa is 0.150 and in Balapur 0.150g, in Debra 0.140 and 0.140 in M6DPC. Cocoon shell ratio in Chalsa is $14.45 \%$, in Balapur $14.42 \%$, in Debra $14.72 \%$ and in M6DPC is 13.91 . Pupation rate in Chalsa is $90.58 \%$, in Balapur $94.15 \%$ and in Debra $95.58 \%$ and 94.65 in M6DPC. Evaluation of these P2 dfls of Nistari (Chalsa, Balapur and Debra) in West Bengal at selected Basic seed farms indicated $36.05 \mathrm{Kg} / 100$ dfls with a good pupation rate of $95.7 \%$. In Tamil Nadu, Nistari (Chalsa) revealed an average yield of $41.89 \mathrm{Kg} / 100 \mathrm{dfls}$ with $95 \%$ pupation. In case of M6DPC, it revealed an average yield of $45.12 \mathrm{Kg} / 100 \mathrm{dfls}$ with pupation rate of $94 \%$ and other traits are on par with laboratory performance. In Andhra Pradesh, an average of $52.03 \mathrm{Kg} / 100 \mathrm{dfls}$ (Chalsa) yield with $96.6 \%$ pupation rate and excellent economic traits is indication for quality seed cocoons to realize the benefit of hybrid vigour at commercial level.

\section{Introduction}

The production of hybrid eggs for commercial rearing involves a long chain of interdependent and specialized operations right from the systematic multiplication of the races for production of quality seed cocoons in order to meet the demand of the industry. Usually, the breeders develop many new races/breeds but the maintenance and 
popularization of these races are more difficult and troublesome than developing them (Akio Yamaguchi, 2003). During the course of development of new races, ideal environment and appropriate selection procedures have to be adopted based on the target traits / special characters. Feeding of good quality mulberry, rearing in favourable environment and continuous selection of the targeted traits are absolutely necessary. The important point in the maintenance of silkworm races at breeder's level is to balance the productivity, pupation rate and other characters such as fecundity, hatching, easy rearing, cocoon yield, high quality cocoons. In tropical countries like India, polyvoltine silkworm strains play important role in the production of silk, since they are well acclimatized to the tropical climatic conditions (Datta, 1998). The silk cocoon production is determined by various factors including environment and genotype of the silkworm. National Silkworm Seed Organization (NSSO), Bengaluru has taken responsibility to supply P2 Multivoltine Dfls of popular races in emergency conditions to different states particularly West Bengal for the generation of P1 multivoltine seed cocoons to prepare $\mathrm{F} 1$ (multi $\mathrm{x}$ bi) hybrids. The popular multivoltine races like Nistari (ecotypes viz. Chalsa, Balapur and Debra) and M6DPC of West Bengal state are being maintained at Silkworm Seed Technology laboratory, Kodathi. The P2 Dfls prepared were supplied to various Basic Seed Farms for further multiplication and generated P1 seed cocoons. These seed cocoons are used to prepare Multi $\times$ bi hybrids in that area. Hence, the present study has been taken up at SSTL, Kodathi during 2012-2018 through one-way system of race maintenance.

\section{Materials and Methods}

The popular multivoltine races like Nistari (ecotypes viz. Chalsa, Balapur and Debra), and M6DPC of West Bengal were maintained during 2012-2018 at this institute and conducted 5 rearings in a year for 5 years.

\section{Pattern of brushing}

Nistari (ecotypes viz. Chalsa, Balapur and Debra) and M6DPC are brushed in 'composite laying' pattern. Composite laying is defined as a collection of known number of eggs from 30 individual layings. A composite laying is prepared after the $7^{\text {th }}$ day of incubation i.e., at blue stage by taking 50-100 eggs (tearing the laying by hand) from each laying. All the pieces of one breed are pasted on a slightly thick paper and packed in tissue paper. Care has taken that there is no overflow of gum on the eggs while pasting the pieces, because newly hatched larvae may get stuck with gum. Thus each composite laying consists a source of 20-30 layings with 1,000 -3000 individuals to create wide genetic base (Rao et al., 2006).

\section{Rearing of pure races}

Each composite laying is brushed in one wooden tray of size $2 \times 3^{\prime}$ and in the progression of rearing larvae are rejected periodically and after $3^{\text {rd }}$ moult 300 good larvae / tray is retained in replicated manner. The young age rearing is conducted under strict hygienic conditions with optimum temperature of $28 \pm 1^{\circ} \mathrm{C}$ and relative humidity of $80 \pm 5 \%$. Late age rearing is conducted under optimum room temperature of $25 \pm 1{ }^{\circ} \mathrm{C}$ and relative humidity of $60 \pm 5 \%$. The rearing and mounting of matured larvae are carried out as per the standard rearing procedure out lined by Krishnaswamy (1978) and Datta (1992). The required quantity and quality of mulberry leaves are fed in each feeding. In each instar, the undersized worms are collected from each bed, centrifuged and screened under microscope for pebrine disease. Soon after third moult, all the larvae 
are counted in each batch, if necessary, 3 replications are made by retaining 300 larvae (randomly counted) in each breed. During the rearing period, observations were recorded on quantitative traits of commercial value, such as Fecundity (No), Hatching (\%), Total larval duration (days), Effective Rate of Rearing (ERR) by number \&, by weight (Kg), Cocoon weight $(\mathrm{g})$,Cocoon shell weight $(\mathrm{g})$ and Shell ratio $(\%)$. The data were subjected to one-way system of classification (Kempthorne, 1952).

\section{Grainage operations and Selection procedure}

Bed wise cocoons are harvested, analyzed for quantitative traits and good cocoons were kept for seed. Soon after harvest pupation rate is calculated by shaking each cocoon gently for live pupal sound. Live cocoon number and weight are recorded. Defective cocoons are classified and their number and weight are also recorded. Generally visual selection is followed after calculating all desirable traits. The important parameters employed for cocoon selection are pupation rate, cocoon shape, uniform color, moderate grains and built. The randomly selected cocoons (20 number each for Male \& Female) are subjected to cocoon assessment for cocoon weight, cocoon shell weight and cocoon shell ratio by using electronic balance.

In each bed, 60 good cocoons are retained for egg production through Inter bed crossing. The standard grainage techniques are followed as suggested by Narasimhanna and Ullal (1985). Grainage parameters like male and female percentage, percentage of pairs and dfls were recorded and from each batch 25-30 disease free layings are prepared. Year wise prepared P2 dfls were supplied to different Basic seed farms for further multiplication and rearing was conducted following standard methods of rearing and generated P1 seed cocoons for hybrid preparation.

\section{Results and Discussion}

The mean rearing performance of Nistari ecotypes Chalsa, Balapur and Debra and M6DPC for 5 years were presented in Tables 1 and 2 . The mean fecundity in Chalsa 480,440 in Balapur, 436 in Debra, 446 and in M6DPC. The hatching percent $88.00 \%$ in Chalsa, $88.54 \%$ in Balapur, $89.08 \%$ in Debra and 88.20 in M6DPC. The effective rate of rearing/ 10,000 larvae (ERR) by is 8927 in Chalsa, 9118 in Balapur and in Debra 8898 and 8843 in M6DPC. The ERR by weight is $8.96 \mathrm{Kg}$ in Chalsa, 8.66 Kg in Balapur,8.61 $\mathrm{Kg}$ in Debra and 7.92 in M6DPC. The cocoon weight in Chalsa $0.800 \mathrm{~g}$, and $1.00 \mathrm{~g}$ in Balapur, $1.020 \mathrm{~g}$ in Debra, 1.060 and in M6DPC. The cocoon shell weight in Chalsa is 0.150 and in Balapur 0.150g, in Debra 0.140 and 0.140 in M6DPC. Cocoon shell ratio in Chalsa is $14.45 \%$, in Balapur $14.42 \%$, in Debra $14.72 \%$ and in M6DPC is 13.91 . Pupation rate in Chalsa is $90.58 \%$, in Balapur 94.15\% and in Debra $95.58 \%$ and 94.65 in M6DPC. The total larval duration in Chalsa 23.00h days, in Balapur 22.12h, in Debra it is 22.16h, 23.18h and in M6DPC. Significant differences were revealed in all the three ecotypes for fecundity, ERR by number in Balapur and Debra, Cocoon weight in Chalsa, Balapur and Debra. Significant variations were also recorded for cocoon weight in Chalsa, Balapur and Debra. Shell weight was significant in Balapur and Debra, shell ratio and pupation rate was high in Debra. In M6DPC except for shell ration and total larval duration and good productive traits.

The year wise distributions of different P2 dfls to different states were provided in Table 3. Mean rearing performance of different multivoltine breeds at different Basic Seed Farms in 3 states was depicted in tables 4, 5 and 6. Mean performance of Nistari eco-types (Chalsa, Balapur and Debra) in W.B are presented in Table 4 indicated $36.05 \mathrm{Kg} / 100$ 
dfls with a good pupation rate of $95.7 \%$ with good metric traits. In Tamil Nadu, Nistari (Chalsa) and M6DPC (Table 5) indicated an average yield of $41.89 \mathrm{Kg} / 100$ dfls with $95 \%$ pupation and in $\mathrm{M} 6 \mathrm{DPC}$, it revealed an average yield of $45.12 \mathrm{Kg} / 100 \mathrm{dfl}$ with $94 \%$ pupation rate. In Andhra Pradesh, an average of $52.03 \mathrm{Kg} / 100 \mathrm{dfls}$ (Chalsa) yield with $96.6 \%$ pupation rate and excellent economic traits is indication for quality seed cocoons. Silkworm, Bombyx mori L., is very sensitive to climatic fluctuations and as a consequence silk content in the cocoon is greatly influenced (Rahman and Ahmed, 1988). The stock maintenance results in the present study for 5 years with almost 25 crops showed consistent performance of popular multivoltine races with better egg recovery. The pupation rate indicated $90 \%$ and above in all the three ecotypes (Tables 1 and 2) is an indication for the quality of seed cocoons.

Table.1 Mean rearing performance and egg laying efficiency of Nistari (Chalsa and Balapur) in the laboratory

\begin{tabular}{|l|c|c|c|c|c|c|c|c|c|}
\hline Race / Breed & $\begin{array}{c}\text { Fecundity } \\
(\mathbf{N o})\end{array}$ & $\begin{array}{c}\text { Hatching } \\
(\boldsymbol{\%})\end{array}$ & $\begin{array}{c}\text { ERR } \\
\text { by No. }\end{array}$ & $\begin{array}{c}\text { By } \\
\text { weight } \\
(\mathbf{K g})\end{array}$ & $\begin{array}{c}\text { Cocoon } \\
\text { weight } \\
(\mathbf{g})\end{array}$ & $\begin{array}{c}\text { Shell } \\
\text { Weight } \\
(\mathbf{g})\end{array}$ & $\begin{array}{c}\text { Shell } \\
\text { Ratio } \\
(\boldsymbol{\%})\end{array}$ & $\begin{array}{c}\text { Pupation } \\
(\boldsymbol{\%})\end{array}$ & $\begin{array}{c}\text { LD } \\
(\mathbf{D a y s})\end{array}$ \\
\hline Chalsa Mean & $\mathbf{4 8 0 . 0 0}$ & $\mathbf{8 8 . 0 0}$ & $\mathbf{8 9 2 7 . 0 4}$ & $\mathbf{8 . 9 6}$ & $\mathbf{0 . 0 8}$ & $\mathbf{0 . 1 5}$ & $\mathbf{1 4 . 4 5}$ & $\mathbf{9 0 . 5 8}$ & $\mathbf{2 3 . 1 6}$ \\
\hline F-test & $*$ & $\mathrm{NS}$ & $\mathrm{NS}$ & $\mathrm{NS}$ & $*$ & $\mathrm{NS}$ & NS & NS & NS \\
\hline S. E \pm & 17.39 & 3.070 & 459.353 & 0.676 & 0.07 & 0.01 & 0.66 & 4.23 & 1.96 \\
\hline CD at 5 \% & 51.30 & - & - & 0.18 & 0.25 & - & - & - & - \\
\hline Balapur & $\mathbf{4 4 0}$ & $\mathbf{8 8 . 5 4}$ & $\mathbf{9 1 1 8 . 8 0}$ & $\mathbf{8 . 6 6}$ & $\mathbf{1 . 0 0}$ & $\mathbf{0 . 1 5}$ & $\mathbf{1 4 . 4 2}$ & $\mathbf{9 4 . 1 5}$ & $\mathbf{2 2 . 1 2}$ \\
\hline Mean & & & & & & & & & \\
\hline F-test & $*$ & $*$ & $*$ & NS & $*$ & $*$ & NS & NS & NS \\
\hline S. E \pm & 26.81 & 2.39 & 310.36 & 0.77 & 0.04 & 0.009 & 0.46 & 2.06 & 1.72 \\
\hline CD at 5 \% & 79.10 & 7.06 & 915.58 & - & 0.13 & 0.026 & - & - & - \\
\hline
\end{tabular}

Note: *Significant, NS-Non-significant, LD-larval Duration

Table.2 Mean rearing performance and egg laying efficiency of Debra (Nistari) and M6DPC in the laboratory

\begin{tabular}{|l|c|c|c|c|c|c|c|c|c|}
\hline & $\begin{array}{c}\text { Fecundity } \\
(\mathbf{N o})\end{array}$ & $\begin{array}{c}\text { Hatching } \\
(\mathbf{\%})\end{array}$ & $\begin{array}{c}\text { ERR } \\
\text { by No. }\end{array}$ & $\begin{array}{c}\text { Cocoon } \\
\text { weight } \\
\mathbf{( K g )}\end{array}$ & $\begin{array}{c}\text { Cocoon } \\
\text { Weight } \\
(\mathbf{g})\end{array}$ & $\begin{array}{c}\text { Shell } \\
\text { Weight } \\
(\mathbf{g})\end{array}$ & $\begin{array}{c}\text { Shell } \\
\text { Ratio } \\
(\boldsymbol{\%})\end{array}$ & $\begin{array}{c}\text { Pupation } \\
(\boldsymbol{\%})\end{array}$ & $\begin{array}{l}\text { LD } \\
(\mathbf{D a y s})\end{array}$ \\
\hline Debra Mean & $\mathbf{4 3 6}$ & $\mathbf{8 9 . 0 8}$ & $\mathbf{8 8 9 8}$ & $\mathbf{8 . 6 1}$ & $\mathbf{1 . 0 2}$ & $\mathbf{0 . 1 4}$ & $\mathbf{1 4 . 7 2}$ & $\mathbf{9 5 . 5 8}$ & $\mathbf{2 2 . 1 6}$ \\
\hline F-test & $*$ & $\mathrm{NS}$ & $*$ & $\mathrm{NS}$ & $*$ & $*$ & $*$ & $*$ & $\mathrm{NS}$ \\
\hline S. E \pm & 25.88 & 3.74 & 341.82 & 0.72 & 0.06 & 0.01 & 0.46 & 1.56 & 1.50 \\
\hline CD at 5 \% & $76.36 *$ & - & $1008.38^{*}$ & - & $0.18 *$ & $0.03 *$ & $1.37 *$ & $4.61 *$ & - \\
\hline M6DPC Mean & $\mathbf{4 4 6}$ & $\mathbf{8 8 . 2 0}$ & $\mathbf{8 8 4 4}$ & $\mathbf{7 . 9 2}$ & $\mathbf{1 . 0 6}$ & $\mathbf{0 . 1 4}$ & $\mathbf{1 3 . 9 1}$ & $\mathbf{9 4 . 6 5}$ & $\mathbf{2 3 . 1 8}$ \\
\hline F-test & $*$ & $*$ & $*$ & $*$ & $*$ & $*$ & NS & $*$ & NS \\
\hline S. E \pm & 26.95 & 3.18 & 403.90 & 0.73 & 0.09 & 0.01 & 0.52 & 1.57 & 0.78 \\
\hline CD at 5 \% & $79.51 *$ & $9.39 *$ & $1191.51 *$ & $2.15 *$ & $0.27 *$ & $0.02 *$ & - & $4.65 *$ & - \\
\hline
\end{tabular}

Note: *Significant, NS-Non-significant, LD-larval Duration 
Table.3 Year wise distribution of P2 Multivoltine Dfls to different states

\begin{tabular}{|l|c|c|c|c|c|c|}
\hline \multicolumn{1}{|c|}{ Race } & State & $\mathbf{2 0 1 2 - 1 3}$ & $\mathbf{2 0 1 3 - 1 4}$ & $\mathbf{2 0 1 5 - 1 6}$ & $\mathbf{2 0 1 7 - 1 8}$ & Total \\
\hline Chalsa & West Bengal & 1518 & 1500 & 400 & - & $\mathbf{3 4 1 8}$ \\
\hline Balapur & “ & 105 & 680 & - & - & $\mathbf{7 8 5}$ \\
\hline Debra & “ & 913 & - & - & - & $\mathbf{9 1 3}$ \\
\hline Mcon1 & “ & - & 90 & - & - & $\mathbf{9 0}$ \\
\hline M6DPC & “ & - & 400 & - & - & $\mathbf{4 0 0}$ \\
\hline Chalsa & Tamil Nadu & 405 & 1625 & 570 & - & $\mathbf{2 6 0 0}$ \\
\hline Balapur & “ & - & 1510 & - & - & $\mathbf{1 5 1 0}$ \\
\hline Debra & “ & - & 260 & - & - & $\mathbf{2 6 0}$ \\
\hline M6DPC & “ & - & 400 & - & - & $\mathbf{4 0 0}$ \\
\hline Chalsa & Andhra Pradesh & 457 & 700 & 75 & 120 & $\mathbf{1 3 5 2}$ \\
\hline Total & & $\mathbf{3 3 9 8}$ & $\mathbf{7 1 6 5}$ & $\mathbf{1 0 4 5}$ & $\mathbf{1 2 0}$ & $\mathbf{1 1 7 2 8}$ \\
\hline
\end{tabular}

Table.4 Mean rearing performance of Nistari (Chalsa, Balapur and Debra) in West Bengal Basic seed farms

\begin{tabular}{|c|c|c|c|c|c|c|c|c|c|c|c|}
\hline \multirow[t]{2}{*}{ Race } & \multirow[t]{2}{*}{ Year } & \multirow{2}{*}{$\begin{array}{l}\text { No. } \\
\text { of } \\
\text { Dfls }\end{array}$} & \multirow{2}{*}{$\begin{array}{l}\text { Fec. } \\
\text { (No) }\end{array}$} & \multirow{2}{*}{$\begin{array}{l}\text { Hat } \\
(\%)\end{array}$} & \multicolumn{2}{|c|}{ Yield/100 dfls } & \multirow{2}{*}{$\begin{array}{l}\text { Coc. } \\
\text { wt } \\
\text { (g) }\end{array}$} & \multirow{2}{*}{$\begin{array}{l}\text { Shell } \\
\text { wt (g) }\end{array}$} & \multirow{2}{*}{$\begin{array}{l}\text { S.R } \\
(\%)\end{array}$} & \multirow{2}{*}{$\begin{array}{l}\text { Pup. } \\
\text { rate } \\
(\%)\end{array}$} & \multirow{2}{*}{$\begin{array}{l}\text { Coco } \\
\text { ons / } \\
\mathrm{Kg}\end{array}$} \\
\hline & & & & & No & $\begin{array}{l}\text { wt } \\
(\mathrm{Kg})\end{array}$ & & & & & \\
\hline Chalsa & 2012-13 & 1405 & 438 & 91.3 & 24156 & 23.60 & 1.018 & 0.129 & 12.76 & 95 & 1010 \\
\hline Balapur & $2012-13$ & 75 & 533 & 95.5 & 43076 & 48.40 & 1.134 & 0.158 & 13.93 & 99 & 890 \\
\hline Balapur & 2013-14 & 260 & 488 & 92.0 & 29196 & 31.73 & 1.180 & 0.160 & 13.55 & 94 & 900 \\
\hline Debra & $2012-13$ & 900 & 442 & 92.2 & 27627 & 26.50 & 0.965 & 0.125 & 12.91 & 95 & 1047 \\
\hline Total/Mean & & 2640 & 475 & 92.7 & 34763 & 36.00 & 1.074 & 0.143 & 13.28 & 95.7 & 962 \\
\hline
\end{tabular}

Table.5 Mean rearing performance of Chalsa, M6DPC in Tamil Nadu Basic seed farms

\begin{tabular}{|c|c|c|c|c|c|c|c|c|c|c|c|}
\hline \multirow[t]{2}{*}{ Race } & \multirow[t]{2}{*}{ Year } & \multirow{2}{*}{$\begin{array}{l}\text { No. of } \\
\text { Dfls }\end{array}$} & \multirow{2}{*}{$\begin{array}{l}\text { Fec. } \\
\text { (No) }\end{array}$} & \multirow{2}{*}{$\begin{array}{l}\text { Hat } \\
(\%)\end{array}$} & \multicolumn{2}{|c|}{ Yield/100 dfls } & \multirow{2}{*}{$\begin{array}{l}\text { Coc. } \\
\text { wt } \\
\text { (g) }\end{array}$} & \multirow{2}{*}{$\begin{array}{l}\text { Shell } \\
\text { wt (g) }\end{array}$} & \multirow{2}{*}{$\begin{array}{l}\text { S.R } \\
(\%)\end{array}$} & \multirow{2}{*}{$\begin{array}{l}\text { Pup. } \\
\text { rate } \\
(\%)\end{array}$} & \multirow{2}{*}{$\begin{array}{l}\text { Coco } \\
\text { ons / } \\
\text { Kg }\end{array}$} \\
\hline & & & & & No & $\begin{array}{l}\text { wt } \\
(\mathrm{Kg})\end{array}$ & & & & & \\
\hline Chalsa & 2013-14 & 2865 & 456 & 93.9 & 36003 & 41.44 & 1.150 & 0.132 & 11.47 & 94 & 868 \\
\hline Chalsa & 2015-16 & 470 & 450 & 93.2 & 39171 & 42.34 & 1.081 & 0.129 & 11.93 & 96 & 925 \\
\hline Total/Mean & - & 3335 & 453 & 93.5 & 37587 & 41.89 & 1.115 & 0.130 & 11.56 & 95 & 896 \\
\hline M6DPC & $2012-13$ & 400 & 431 & 91.0 & 41398 & 45.12 & 1.089 & 0.135 & 11.65 & 94 & 917 \\
\hline
\end{tabular}


Table.6 Mean rearing performance of Nistari (Chalsa) in Andhra Pradesh Basic seed farms

\begin{tabular}{|c|c|c|c|c|c|c|c|c|c|c|c|}
\hline \multirow[t]{2}{*}{ Race } & \multirow[t]{2}{*}{ Year } & \multirow{2}{*}{$\begin{array}{l}\text { No. } \\
\text { of } \\
\text { Dfls }\end{array}$} & \multirow{2}{*}{$\begin{array}{l}\text { Fec. } \\
\text { (No) }\end{array}$} & \multirow{2}{*}{$\begin{array}{l}\text { Hat } \\
(\%)\end{array}$} & \multicolumn{2}{|c|}{ Yield/100 dfls } & \multirow{2}{*}{$\begin{array}{l}\text { Coc. } \\
\text { wt (g) }\end{array}$} & \multirow{2}{*}{$\begin{array}{l}\text { Shell. } \\
\text { wt (g) }\end{array}$} & \multirow{2}{*}{$\begin{array}{l}\text { S.R } \\
(\%)\end{array}$} & \multirow{2}{*}{$\begin{array}{l}\text { Pup. } \\
\text { rate } \\
(\%)\end{array}$} & \multirow{2}{*}{$\begin{array}{l}\text { Coco } \\
\text { ons / } \\
\mathbf{K g}\end{array}$} \\
\hline & & & & & No & $\begin{array}{l}\mathbf{w t} \\
(\mathbf{K g})\end{array}$ & & & & & \\
\hline Chalsa & 2015-16 & 650 & 457 & 96.0 & 38580 & 45.82 & 1.188 & 0.130 & 10.94 & 96 & 875 \\
\hline Chalsa & $2017-18$ & 70 & 477 & 94.8 & 43266 & 54.28 & 1.270 & 0.163 & 12.84 & 98 & 797 \\
\hline Chalsa & $2017-18$ & 50 & 479 & 96.5 & 44520 & 56.00 & 1.260 & 0.171 & 13.57 & 95 & 795 \\
\hline Total/Mean & - & 770 & 471 & 95.7 & 42122 & 52.03 & 1.239 & 0.154 & 12.45 & 96.6 & 822 \\
\hline
\end{tabular}

It was reported that (Pillai and Krishnaswamy, 1989) good seed cocoon quality with higher pupation rate is an indication for high egg production is due to care taken at various levels and handling methods during seed crop rearing. The quality of seed cocoon and that of egg yield are directly related and the number of dead pupae varies from race to race in different seasons (Ramamohan Rao et al., 1989). The climatic condition especially temperature, humidity and leaf quality during the rearing seasons is highly variable. The highest mean values recorded in Balapur, Debra and M6DPC (Tables 1-3) for the majority of the economic traits indicated their superiority and stable for all the seasons. Eberhart and Russell (1966) defined a stable genotype as one with high mean, regression co-efficient of unity and a minimum deviation from the regression line. The results revealed that the Nistari (Balapur and Debra) and M6DPC seed cocoons are better source for the preparation of hybrids. Basavaraja et al., (2001) indicated that the original breed characters such as larval pattern, cocoon color, cocoon shape and cocoon wrinkles are to be maintained and their purity is measured on the basis of expression (magnitude) of hybrid vigor in every cycle by the breeder. The superior performance of Balapur and Debra in the West Bengal Basic seed farms (Table 4) and Chalsa in Tamil Nadu and Andhra Pradesh have shown consistent results (Tables $5 \& 6$ ) with excellent pupation and other metric traits. It is concluded that the Races / breeds can be maintained by following the above outlined procedure is essential to minimize loss and to realize the benefit of hybrid vigor at commercial level.

\section{Acknowledgement}

The authors are thankful to the Technical staff of this institute for assistance in experimental rearing and Scientists of NSSO Basic Seed Farms of respective states for their assistance in experimental rearings and help.

\section{References}

Akio Yamaguchi (2003). Maintenance of bivoltine silkworm races at Breeder's level. Concept paper in Mulberry silkworm Breeders summit held during 18-19 July.2003 at APSSRDI, Hindupur, India.

Basavaraja, H.K; N. Suresh Kumar, N. Mal Reddy, G. V. Kalpana, S. Nirmal Kumar, K.P Jayaswal, P. G. Joge, A. K. Palit and R. K. Datta. (2001). New system of maintenance and multiplication of CSR breeds. Indian Silk. June 40(2): 5-8.

Datta R. K (1992). Guidelines for bivoltine rearing. Bulletin. Central Silk Board, Bangalore, India.

Datta R.K (1998) Utilisation of mulberry and silkworm germplasm and importance of database management. Seminar on 
Mulberry and silkworm germplasm $9^{\text {th }}$ Jan. Silkworm and Mulberry germplasm station, Hosur. Tamil Nadu, India.

Eberhart and W. A. Russell (1966) Stability parameters for comparing varieties. Crop Sci. (6); 36-40.

Kempthorne, O. (1952). The design and analysis of experiments. John Wiley and sons. pp. 345. New York, Inc. Chapman and Hall Ltd., London

Krishnaswamy, S. (1978) New Technology of Silkworm Rearing, Bulletin No.2 Central Sericultural Research and Training Institute, Mysore, India, 1-23.

Narasimhanna, M.N. and Ullal, S. Hand book of sericulture, Central Silk Board, Bangalore

Pillai, S.V and Krishnaswamy, S. (1989). Growth studies in silkworm under tropical conditions-VI. An assessment on the fecundity of silkworm breeds in relation to their growth. Ind. J. Seric. 28(1): 44-52.

Rao C.G.P, Seshagiri, S.V., Ramesh, C., Ibrahim Basha, K., Nagaraju, $\mathrm{H}$ and Chandrasekharaiah (2006). Evaluation of genetic potential of the polyvoltine silkworm (Bombyx mori L.) germplasm and Identification of parents for breeding programme. J. Zhenjiang Univ. Science B. 7(3): 215-220.

Rahman, S. M. and S. U. Ahmad (1988) Stability analysis for silk yield in some promising genotypes of Silkworm, Bombyx mori L. Proc. of International Congress of Tropical Sericulture practices, CSB Bangalore, India. III. 27-30.

Ramamohan Rao, P. M. K. Naomani and H. K. Basavaraja (1989). Some observations on melting in bivoltine breeds of the silkworm Bombyx mori L. Sericologia (3); 876-879.

\section{How to cite this article:}

Vijaya Kumari, K.M., P. Sudhakara Rao, R. Saravana Kumar, S. Vidyunmala and Mishra, R.K. 2019. Maintenance of Popular Multivoltine Races for Seed Cocoon Generation and their Performance at Basic Seed Farms. Int.J.Curr.Microbiol.App.Sci. 8(05): 2324-2330. doi: https://doi.org/10.20546/ijcmas.2019.805.274 